\title{
Characterization of Diesel Degrading Bacterial Species from Contaminated Tropical Ecosystem
}

\author{
Obinna Chukwuemeka Nwinyi ${ }^{1 *}$, Ijeoma Akudo Kanu ${ }^{1}$, Ayano Tunde ${ }^{2}$, Kolawole Oluseyi \\ Ajanaku $^{3}$ \\ ${ }^{1}$ Microbiology Laboratory; Department of Biological Sciences; School of Natural and Applied Sciences; College of \\ Science and Technology; Covenant University; Ota; Ogun State - Nigeria. ${ }^{2}$ Department of Biological Sciences; \\ Ajayi Crowther University; Oyo; Oyo State - Nigeria. ${ }^{3}$ Central Research Laboratory; Department of Chemistry; \\ School of Natural and Applied Sciences; College of Science and Technology; Covenant University; Ota; Ogun State \\ - Nigeria
}

\begin{abstract}
The bacterial diversity in a diesel contaminated tropical soil was investigated using diesel oxidation in gradient cultures dynamics ( $\mathrm{pH}$ and $\mathrm{OD}$ ) of the pure cultures. The diesel dependent growths of these isolates were assessed for 15 days by monitoring the gradient fluxes in the $\mathrm{pH}$ and Optical density $O D$ of the media. Results showed an increase in $O D$ as well as fluctuations in $\mathrm{pH}$ values. The mean OD data obtained was 0.515-1.187 with pH of 6.957.2. From the morphological and biochemical characterization and comparison with respect to the standard references, the isolates $S_{1} P_{1}, S_{3} P_{3}, S_{2} P_{2}, S_{2} P_{1}$, and $S_{3} P_{2}$ were presumably the members of the genera Bacillus, Pseudomonas and Mycobacterium species. From the study, it was apparent that the tropical ecosystems contained unique organisms with the ability to deal with diesel contamination.
\end{abstract}

Key words: Diesel, Optical density, Turbidity, Tropical Ecosystem, bacterial strains, pH

\section{INTRODUCTION}

Globally, there is a growing concern about the risks of environmental contamination from the exploration, transport and storage of petroleum. With a maximum crude oil production capacity of 2.8 million barrels per day, Nigeria ranks as one of the Africa's largest producers of oil and the sixth largest oil producing country in the world. In Nigeria, the Niger Delta is the hub of oil exploration and transportation. According to Chikere et al. (2009), this ecological zone and its surrounding offshore areas supply above $80 \%$ of the country's crude oil. In addition, the petroleum and petrochemical products are produced, refined and handled in this region. With the over- dependence on the vehicles for the transportation of the petroleum products, accidental spills are unabated. Gas stations and other storage containers have life spans that are minimal, and as a result, soil and aquifer contamination cases emanate from these sources (Brito et al. 2010; Alessandra et al. 2012).

Diesel fuel, also known as the Automotive Gas Oil (AGO), is a complex and common pollutant. It consists mainly of aliphatic hydrocarbons ranging from $\mathrm{C}_{9}$ to $\mathrm{C}_{23}$ and number of aromatic compounds (Ciric et al. 2009). The environmental impacts of diesel when spilled include reduction of plant growth through direct toxic effect on the plants, reduced germination, and unsatisfactory soil condition due to insufficient aeration of the

*Author for correspondence: nwinyiobinna@gmail.com 
pore space between the soil particles. Thus, the biological functioning of microbial communities which are central to the biogeochemical cycling of ecosystem is truncated. This consequently affects the productivity of such ecosystems (Okerentugba and Ezeronye 2003; Scullion 2006; Kayode-Isola et al. 2008).

Since the 1940's, the susceptibility of hydrocarbons to microbial degradation is well documented (Zobell 1946) .The extent of the degradation varies according to their chemical structures.

Previous studies on bioremediation have yielded good results for the decontamination of diesel oil contaminated soil in temperate climates (Huang et al. 2004; Ghazali et al. 2004; Bento et al. 2005; Riffaldi et al. 2006). However, the bacterial diversity of tropical ecosystems is less explored. In bioremediation, the detoxification of organic contaminants has been established as an efficient, economic, versatile and environmentally sound treatment (Margesin et al. 2003; Nweke and Okpokwasili 2004; Kaplan and Kitts 2004; Quatrini et al. 2008). This is possible because the microorganisms have catabolic gene pool that is necessary for synthesizing the enzymes that can mediate the critical steps in diesel oil degradation.

Several, bacterial genera have exhibited great abilities in utilizing the hydrocarbon substrates (Bogan et al. 2003; Chikere et al. 2009). These bacterial species are wide spread in pristine and oil polluted environments (Hamamura et al. 2006; Cappello et al. 2007; Van Beilen and Funhoff 2007). Culture-independent molecular techniques using 16S rRNA gene sequences and certain independent isolation techniques have been used in characterizing these bacterial species, which include: Gram-negative bacteria such as Acinetobacter, Pseudomonas, Alkanivorax and related genera. There are other specific organisms that are capable of degrading the diesel oil. These include Bacillus subtilis, Bacillus sp., Alcaligenes sp., Flavobacterium sp.,Micrococcus roseus, Corynebacterium sp., Citrobacter freundii, Klebsiella, Arthrobacter, Acromobacter, Alcaligenes, Nocardia and actinomycetes (Amund, 2000; Wackett and Hershberger 2001; Parales et al. 2002).

Chikere et al. (2009) reported that the experimental and edaphic variation existed between the temperate and of tropical environments. There could be a possibility of domination of Gram negative Proteobacteria and Cytophaga-Flavobacterium-Bacteroides group in bioremediation (Macnaughton et al. 1999; Kaplan and Kitts 2004). It has also been reported, that Gram positive bacteria often dominate the sites of bioremediation due to their metabolic versatility (Chikere et al. 2009).

In this study, the bacterial diversity in a diesel contaminated tropical soil was investigated using the diesel oxidation in gradient cultures dynamics ( $\mathrm{pH}$ and turbidity dynamics) of the pure cultures.

\section{MATERIAL AND METHODS}

\section{Chemicals and Reagents}

The $\left(\mathrm{NH}_{4}\right)_{2} \mathrm{SO}_{4}, \mathrm{MgSO}_{4} \cdot 7 \mathrm{H}_{2} \mathrm{O}, \mathrm{Ca}\left(\mathrm{NO}_{3}\right)_{2} \cdot 4 \mathrm{H}_{2} \mathrm{O}$, $\mathrm{K}_{2} \mathrm{HPO}_{4}, \mathrm{KH}_{2} \mathrm{PO}_{4}$, and $\mathrm{NaCl}$ of analytical grades were obtained from Merck Germany. Nutrient agar and nutrient broth were obtained from Micro Master India. Urease base agar, starch agar, methyl red and voges proskauer medium and peptone water were procured from the Microbiology Laboratory, Covenant University. Petroleum diesel fuel, produced according to EN 590:2004, was purchased from a gas station in Canaanland Ota, Ogun State Nigeria.

\section{Stock solutions and Media}

All the enrichment and degradation experiments were performed using chloride-free minimal salts (MS) medium as described by Kim and Picardal (2000) with slight modification. The medium consisted of $(\mathrm{g}) 0.5\left(\mathrm{NH}_{4}\right)_{2} \mathrm{SO}_{4}, 0.1 \mathrm{MgSO}_{4} \cdot 7 \mathrm{H}_{2} \mathrm{O}$, $0.076 \mathrm{Ca}\left(\mathrm{NO}_{3}\right)_{2} \cdot 4 \mathrm{H}_{2} \mathrm{O}$ and $40 \mathrm{~mm}$ phosphate buffer (pH 7.25). Solid MS medium was made by the addition of $1.8 \%$ Bacto-agar (Difco Laboratories, Detriot, MI USA). MS medium was supplemented with the diesel oil.

\section{Enrichment of microbial communities}

Soil samples were collected from the contaminated sites around the store houses of the power (generator) houses in Covenant University, Nigeria. Diesel degrading bacteria were initially isolated by the conventional enrichment culture methods. For this $5.0 \mathrm{~g}$ of the soil samples were mixed with MS medium contained in a conical flask $(200 \mathrm{~mL})$. The medium was amended with diesel $(0.2 \% \mathrm{v} / \mathrm{v})$ as the primary carbon source. The flasks were incubated on a shaker (Model $\mathrm{H} 2 \mathrm{Q}-\mathrm{X} 300$ ) at $65 \mathrm{rpm}$ at $30^{\circ} \mathrm{C}$ for 14 days. Subsequent transfers from these enrichments were 
made fortnightly by using the same methods and conditions. After about one month, the enrichment cultures were transferred to a fresh medium using a $15 \%$ inoculum and continued cultivation under the same conditions. Subsequent transfers were carried out using $2 \%$ inoculum and the procedure was repeated for five successive times.

\section{Determination of Physicochemical parameters of soil}

The soil samples were collected randomly at the site of study using a clean container. After removing the stones by sieving, the soil samples were thoroughly mixed and stored in $20 \mathrm{~mL}$ McCartney bottles. The sample were analyzed for $\mathrm{PAH}$, heavy metals and $\mathrm{pH}$.

\section{Inoculum preparation}

Cultures were incubated on a freshly prepared sterile nutrient broth in cotton wool stoppered balch tubes and incubated at $30^{\circ} \mathrm{C}$ for $120 \mathrm{~h}$. The cells were harvested by centrifugation at $35 \times 100$ rpm for $50 \mathrm{~min}$, washed two times in phosphate buffer saline at $\mathrm{pH}$ of 7.25 , transferred into a sterile $2.0 \mathrm{~mL}$ eppendorf tubes and re-suspended in MS medium as previously described by (Nwinyi 2008, 2011) to an optical density of 0.4 at $600 \mathrm{~nm}$. The inocula were used for the growth and degradation studies.

\section{Isolation, purification and characterization of diesel degrading bacterial species}

Pure cultures from the diesel-enriched media were isolated by plating $1.0 \mathrm{~mL}$ of the enriched cultures onto minimal salt (MS) agar, sprayed with diesel on the surface. This was incubated in dark at 28 $32^{\circ} \mathrm{C}$ for five days. Colonies were periodically transferred to MS agar to obtain the pure culture. Using the morphological examinations, bacterial species were isolated and sub-cultured onto separate agar plates. The pure cultures were incubated at $37^{\circ} \mathrm{C}$ for $18-24 \mathrm{~h}$. These were named as $\mathrm{S}_{1} \mathrm{P}_{1}, \mathrm{~S}_{3} \mathrm{P}_{3}, \mathrm{~S}_{2} \mathrm{P}_{2}, \mathrm{~S}_{2} \mathrm{P}_{1}, \mathrm{~S}_{3} \mathrm{P}_{2}$ and classified using the standard cultural and morphological techniques and comparison with standard reference organisms (Cowan 1985; Olutiola et al. 1991). The following tests were carried out: Gram stain, morphology, catalase, oxidase, colony motility, methyl red, voges proskauer, indole, nitrate reduction, gelatin hydrolysis, spore test, starch hydrolysis, coagulase citrate and sugar utilization.
Growth on diesel as carbon and energy source Pure cultures were tested for their ability to degrade the diesel. The tests were performed in balch tubes containing MS medium $(8 \mathrm{~mL})$ supplemented with the diesel, which were inoculated by the pure cultures at $10^{5}$ cells $/ \mathrm{mL}$. Tubes were incubated in shaker (Model H2Q-X $300)$ at $65 \mathrm{rpm}$ at $30^{\circ} \mathrm{C}$ for 15 days. An abiotic control was set up with the inoculated control (MS medium and diesel oil devoid of organism) incubated at the same conditions. Measurements of the optical density (OD) and $\mathrm{pH}$ were carried out at $0,5,7,12$ and 15 days interval. Optical density was measured at $600 \mathrm{~nm}$ using Genesys 10 UVS Spectrophotometer.

\section{Statistical analysis}

Statistical tests (mean and standard deviation) were performed using the SPSS 15.0 computer software programme.

\section{RESULTS AND DISCUSSION}

The concentrations of the petroleum hydrocarbon in the contaminated soil as shown in Table 1 included: fluorene $1.99 \mathrm{ppm}$, Indeno (1, 2, 3-cd) and pyrene 29.11ppm; acenapthalene, acenaphthene and phenanthrene were not detected. The $\mathrm{pH}$ of the polluted soil was 6.54.

The isolates $\mathrm{S}_{1} \mathrm{P}_{1}$, and $\mathrm{S}_{2} \mathrm{P}_{2}$ were motile, catalase positive, Gram positive rod, incapable of fermenting glucose. The morphology and biochemical characterization suggested them similar to the members of the genus Bacillus sp. The isolates $\mathrm{S}_{3} \mathrm{P}_{3}$ and $\mathrm{S}_{3} \mathrm{P}_{2}$ were motile, catalase positive, citrate positive and Gram negative rods. The data of Tables 2 and 3 showed that the isolates $\left(\mathrm{S}_{3} \mathrm{P}_{3}, \mathrm{~S}_{3} \mathrm{P}_{2}\right)$ were similar to the members of the genus Pseudomonas.

Table 1 - Hydrocarbons detected at the selected site.

\begin{tabular}{ll}
\hline (PAH Hydrocarbons) & Selected soil \\
\hline Physical appearance & dark loamy (silt, sand and \\
& gravel) \\
& Not detected \\
& Not detected \\
& $1.99 \mathrm{ppm}$ \\
& Not detected \\
& $29.11 \mathrm{ppm}$ \\
\hline
\end{tabular}


Table 2 - Morphological characteristics of the pure bacterial isolates.

\begin{tabular}{llllll}
\hline & $\mathbf{S}_{\mathbf{1}} \mathbf{P}_{\mathbf{1}}$ & $\mathbf{S}_{\mathbf{3}} \mathbf{P}_{\mathbf{3}}$ & $\mathbf{S}_{\mathbf{2}} \mathbf{P}_{\mathbf{2}}$ & $\mathbf{S}_{\mathbf{2}} \mathbf{P}_{\mathbf{1}}$ & $\mathbf{S}_{\mathbf{3}} \mathbf{P}_{\mathbf{2}}$ \\
\hline Shape & Rods & Rods & Rods & Rods & Rods \\
$\begin{array}{l}\text { Colour } \\
\text { Pigmentation }\end{array}$ & whitish & Creamy/yellowish & whitish & Yellowish orange & Creamy/yellowish \\
$\begin{array}{l}\text { Optical Features } \\
\text { Abundance of } \\
\text { Growth }\end{array}$ & Translucent & Green Pigment & No Pigment & No Pigment & Green Pigment \\
& Large & Moderate & Transparent & Transparent & Translucent \\
Large & Moderate & Moderate \\
\hline
\end{tabular}

Table 3 - Cultural and biochemical characteristics of pure bacterial species capable of degrading diesel.

\begin{tabular}{|c|c|c|c|c|c|}
\hline Gram's Reaction & $\begin{array}{c}\mathbf{S}_{\mathbf{1}} \mathbf{P}_{\mathbf{1}} \\
+ \text { short rods } \\
\text { in clusters }\end{array}$ & $\begin{array}{c}\mathbf{S}_{\mathbf{3}} \mathbf{P}_{\mathbf{3}} \\
\text { - short rods in } \\
\text { chains }\end{array}$ & $\begin{array}{c}\mathbf{S}_{\mathbf{2}} \mathbf{P}_{\mathbf{2}} \\
+ \text { short rods } \\
\text { in clusters }\end{array}$ & $\begin{array}{c}\mathbf{S}_{\mathbf{2}} \mathbf{P}_{\mathbf{1}} \\
+ \text { shortrods }\end{array}$ & $\frac{\mathbf{S}_{\mathbf{3}} \mathbf{P}_{\mathbf{2}}}{\text { clustered rods }}$ \\
\hline Motility Test & + & + & + & - & + \\
\hline Acid-Fast Stain & - & - & - & - & - \\
\hline Spore Stain & + & - & + & - & - \\
\hline Citrate Test & & + & & + & + \\
\hline Catalase Test & + & + & + & + & + \\
\hline Urease Test & + & - & + & - & + \\
\hline Indole Test & - & - & - & - & - \\
\hline MR Test & - & - & - & - & - \\
\hline VP Test & - & - & - & - & - \\
\hline Growth at $35^{\circ} \mathrm{C}$ & + & + & + & + & + \\
\hline $\begin{array}{l}\text { Growth at } \mathrm{pH} \text { at } \\
6.0\end{array}$ & + & + & + & + & + \\
\hline $\begin{array}{l}\text { Growth in } 5 \% \\
\mathrm{NaCl}\end{array}$ & + & + & + & + & + \\
\hline $\begin{array}{l}\text { Starch } \\
\text { Hydrolysis }\end{array}$ & + & + & + & + & + \\
\hline *Glucose & - & & & & - \\
\hline *Lactose & - & & & & - \\
\hline
\end{tabular}

+: Positive Reaction, -: Negative Reaction, *: Sugar Fermentation Tests

Diesel oil is one of the most important combustible fuels used to power various engines. However, it also presents as one of the leading harmful pollutants in the environment, contaminating both the land and water. The need to clean-up these sites has led to the development of effective bioremediation techniques (Hopper 1989). Leahy and Cowell (1990), demonstrated that microorganisms were the main degraders of petroleum hydrocarbons in contaminated ecosystems. Enrichments to isolate oil-degraders using diesel as sole carbon and energy source have generated various microorganisms from several genera (Jirasripongpun 2002).

In the present study, six bacterial species namely $\mathrm{S}_{1} \mathrm{P}_{1}, \mathrm{~S}_{3} \mathrm{P}_{3}, \mathrm{~S}_{2} \mathrm{P}_{2}, \mathrm{~S}_{2} \mathrm{P}_{1}, \mathrm{~S}_{3} \mathrm{P}_{2}$ with potentials in degradation of diesel were isolated. During the growth of the isolates on diesel, the cell numbers increased. Optical density, $\mathrm{pH}$ and microbial growth in the diesel contaminated soil were evaluated by monitoring the changes in the optical density as well as the gradient fluxes in the $\mathrm{pH}$ of the medium (Figs. 1-5). The observed increase in the OD values and $\mathrm{pH}$ was agreeable with the studies on hydrocarbon degradation (Kim and Picardal 2000; Nwinyi et al. 2008, Nwinyi 2011).

The colour of the enrichment medium changed from yellow to green which could be due to the presence of Pseudomonas sp. Studies have reported that oil polluted soils are often dominated with Gram negative bacteria (Kaplan and Kitts 2004; Chikere et al. 2009). The present results corroborated the findings of Ouatrini et al. (2008) who isolated Rhodococcus, Gordonia and Norcadia species as the dominant hydrocarbon degraders from a hydrocarbon contaminated shorelines.

There are several reports of bioremediation of pollutants by Bacillus sp. occurring in the extreme environments. Ijah and Antai (2003) reported that Bacillus sp. was the predominant isolate of all the crude oil utilizing bacteria they characterized from highly polluted soil samples. Bacillus sp. has been termed as more tolerant to high levels of hydrocarbons in soil due to its resistant endospores. 


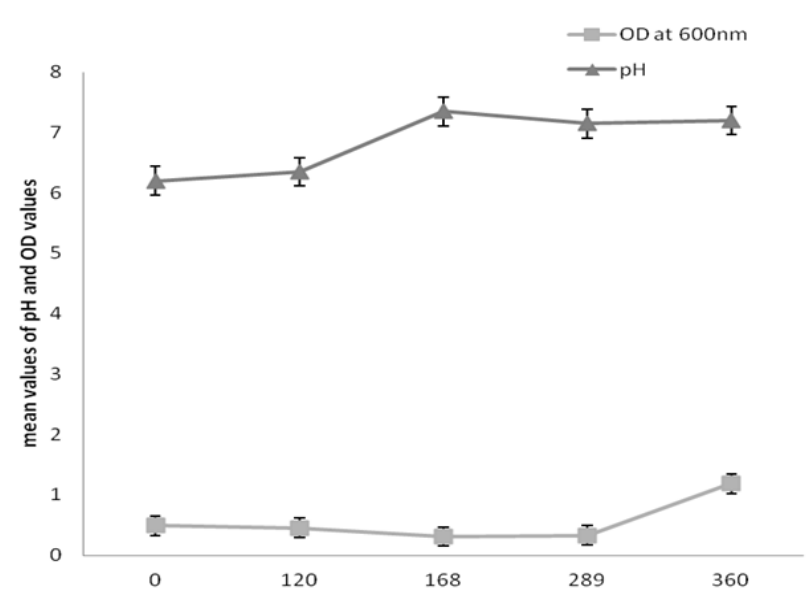

Figure 1 - Diesel -dependent growth (OD) and $\mathrm{pH}$ values of the enrichment medium of Bacillus sp. strain $\mathrm{S}_{1} \mathrm{P}_{1}$ at 15 days incubation. Data represent the mean triplicate tubes for time zero and the final time. The error bars were due to differential responses of cells during measurements. The control initial $\mathrm{pH}$ reading was 6.0 , and the control OD reading was 0.414 .

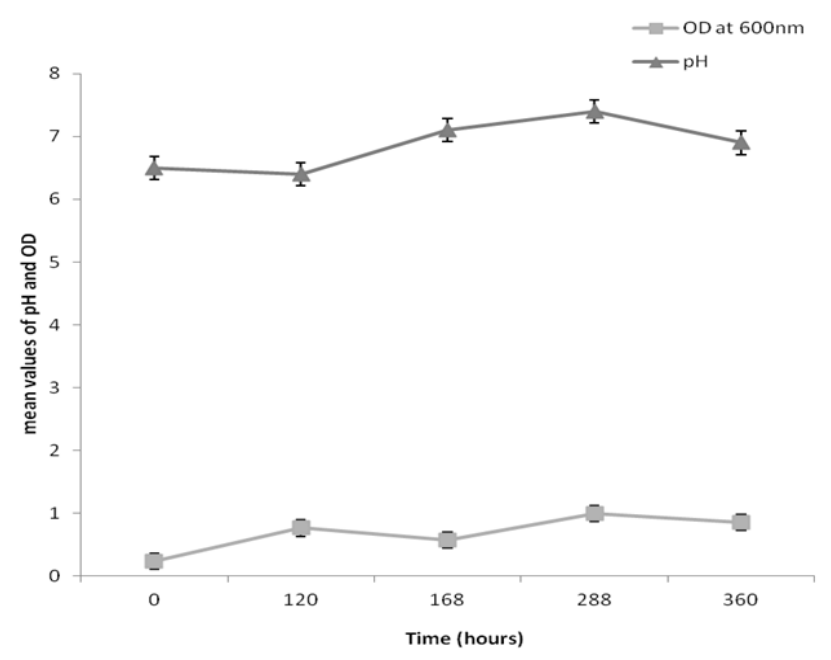

Figure 2 - Diesel -dependent growth (OD) and pH values of the enrichment medium of Pseudomonas sp. strain $\mathrm{S}_{3} \mathrm{P}_{3}$ at 15 days incubation. Data represent the mean triplicate tubes for time zero and the final time. The error bars were due to differential responses of cells during measurements. The control sample initial $\mathrm{pH}$ reading was 6.0 , while the control sample initial OD reading was 0.414 .
In this study, OD readings increased from 0.491 to 1.187 and $\mathrm{pH}$ also showed a significant increase from 6.2 to 7.2 after two weeks for Bacillus sp. In the studies on microbial utilization of hydrocarbons, it was reported that hydrocarbon degradation often led to the production of organic acids (Amund and Adebiyi 1991; Okpokwasili and James 1995), resulting in a decrease of the $\mathrm{pH}$ (pro-acidity). The increase in $\mathrm{pH}$ towards the alkalinity reported could be due to the behavior of the bacterial cells in diesel oil. It might also be that the organism evolved a different pathway towards the utilization of diesel oil. The Pseudomonas sp. showed a steady increase in OD from 0.238 to 0.858 and a corresponding increase in $\mathrm{pH}$ from $6.5-7.45$ after two weeks. As shown in Figure 3, strain $\mathrm{S}_{2} \mathrm{P}_{2}$ identified as Bacillus sp. had a slow OD increase from 0.446 to 0.494 and $\mathrm{pH}$ of 6.1 - 7.0 during the same incubation period. The strain identified as Mycobacterium sp. had a steady increase from 0.345 to 0.603 after two weeks with an increase in $\mathrm{pH}$ from 6.1 to 7.1 (Fig. 4). Strain $\mathrm{S}_{3} \mathrm{P}_{2}$ identified as Pseudomonas sp. showed an OD increase from 0.359 to 0.515 and $\mathrm{pH}$ increased from 6.1 to 6.95 .

These findings showed that the biodegradation of complex hydrocarbons in nature usually required the cooperation of more than a single species. The microbial populations consisting of the strains belonging to various genera have been detected in petroleum-contaminated soil (Ilori et al. 2006; Kim and Crowley 2007). This suggested that the strains from various genera have their roles in the hydrocarbon transformation processes (Ghazali et al. 2004; Cunliffe and Kertesz 2006). Individual microorganisms can metabolize only a limited range of hydrocarbon substrates; hence assemblages of the mixed populations with overall broad enzymatic capacities would be required to achieve considerable biodegradation of petroleum hydrocarbons.

Based on OD results, the two strains of Pseudomonas sp. and Bacillus sp. were considered as having the highest degradation potentials. The growth dynamics observed might either be due to their constitutive nature of hydrocarbon assimilating capabilities or adaptation of the strains as a result of previous exposure to exogenous hydrocarbons (Adebusoye et al. 2007). 


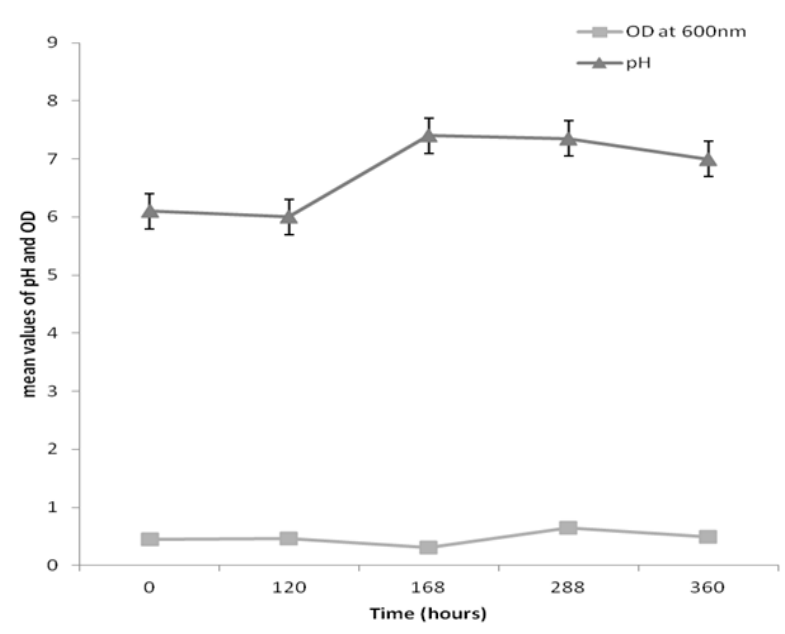

Figure 3 - Diesel dependent growth (OD) and $\mathrm{pH}$ values of the enrichment medium of Bacillus sp. strain $\mathrm{S}_{2} \mathrm{P}_{2}$ at 15 days incubation. Data represent the mean triplicate tubes for time zero and the final time. The error bars were due to differential responses of cells during measurements. The control sample initial $\mathrm{pH}$ reading was 6.0 , while the control sample initial OD reading was 0.414 .

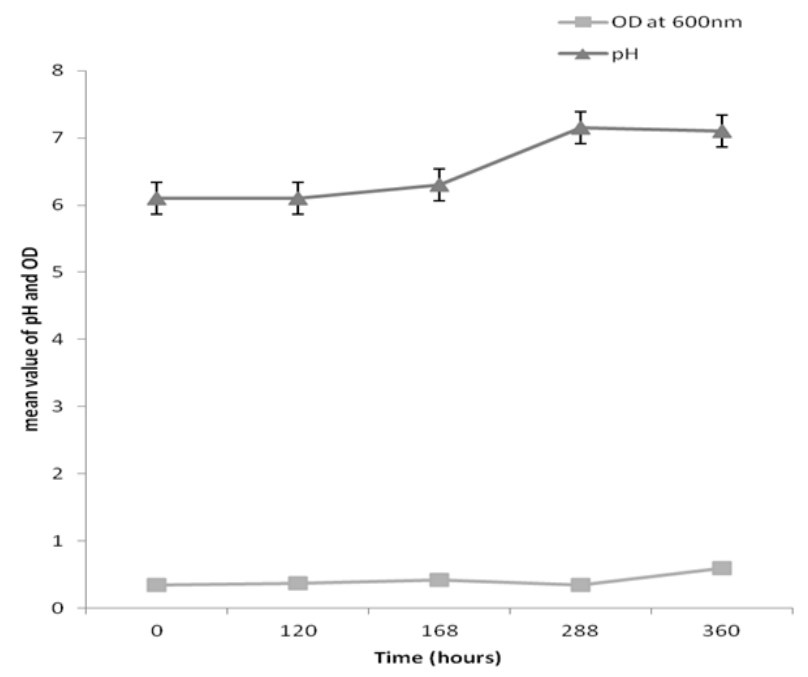

Figure4 - Diesel -dependent growth (OD) and pH values of the enrichment medium of Mycobacterium sp. strain $\mathrm{S}_{2} \mathrm{P}_{1}$ at 15 days incubation. Data represent the mean triplicate tubes for time zero and the final time. The error bars were due to differential responses of cells during measurements. The control sample initial $\mathrm{pH}$. reading was 6.0 , while the control sample initial OD reading was 0.414 .

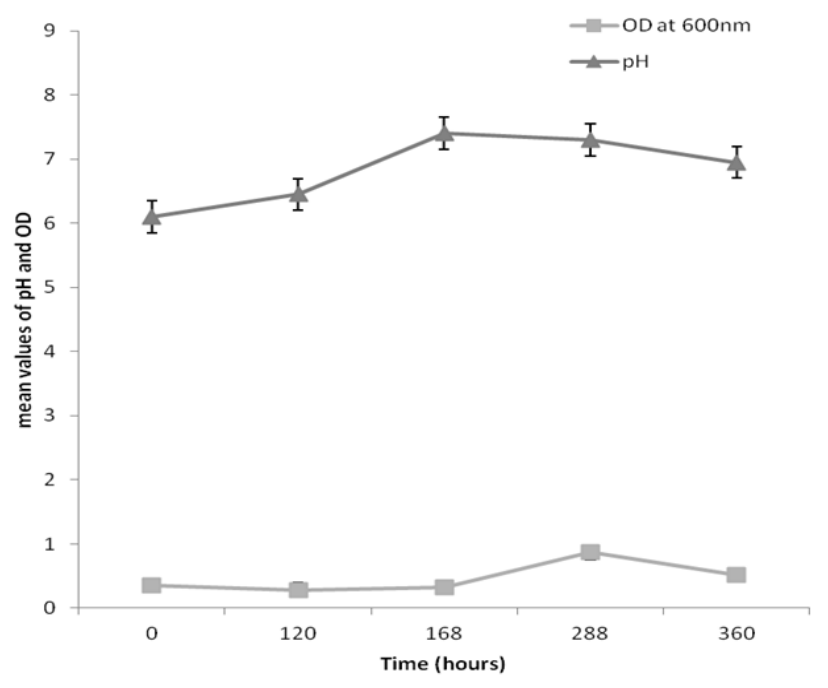

Figure 5 - Diesel -dependent growth (OD) and pH values of the enrichment medium of Pseudomonas sp. strain $\mathrm{S}_{3} \mathrm{P}_{2}$ at 15 days incubation. Data represent the mean triplicate tubes for time zero and the final time. The error bars were due to differential responses of cells during measurements. The control sample initial $\mathrm{pH}$ reading was 6.0 , while the control sample initial OD reading was 0.414 .

\section{CONCLUSION}

Bioremediation is one of the major ways of reclaiming the polluted environments. However, what needs to be done is to determine the environmental factors favorable for the bacterial species. Evidently, the indigenous bacterial species could be used effectively in the bioremediation of diesel contaminated soils of tropical origin. Further studies should be carried out on the catabolic genes or plasmids responsible for the degradation ability of these organisms for strain improvement and prospective use for biotechnological exploitation.

\section{REFERENCES}

Adebusoye SA, Ilori MO, Amund OO, Teniola OD, Olatope SO. Microbial Degradation of Petroleum Hydrocarbons in a Polluted Tropical Stream. World J Microbiol Biotechnol. 2007; 23: 1149-1159.

Alessandra CO, Chagas-Spinelli, Mario TK, Edmilson S, de Lima SG. Bioremediation of a tropical clay soil contaminated with diesel oil. J Environ Management. 2012; 113: 510-516. 
Amund OO, Adebiyi, AG. Effect of viscosity on the biodegradability of automotive lubricating oils. Tribol Intern. 1991; 24:235-237.

Amund OO. The oil-eating microbes: a remedy to the menace of oil pollution. An inaugural lecture delivered at the University of Lagos, Nigeria; 2000.

Bento FM, Camargo FAO, Okeke BC, Frankenberger WT. Comparative bioremediation of soils contaminated with diesel oil by natural attenuation,biostimulation and bioaugmentation. Bioresource Technol. 2005; 96: 1049-1055.

Bogan BW, Lahner LM, SulliVan Beilen WR, Paterek JR. Degradation of straight chain aliphatic and high molecular weight polycyclic aromatic hydrocarbons by a strain of Mycobacterium austroafricanum. J Appl Microbiol. 2003; 94: 230-239.

Brito GCB, Souza DBS, Vasconcelos FCW, Braga LC. The importance of microorganism bioprospection in areas contaminated by products derived from oil. Revista em Agronegocios e Meio Ambiente. 2010; 3 (3) 291-310.

Cappello S, Caneso G, Zampino D, Monticelli L, Maimone G, Dnearo R, et al. Microbial community dynamics during assays of harbour oil spill bioremediation: a microscale simulation study. $J$ Appl Microbiol. 2007; 102: 184-194.

Chikere CB, Okpokwasili GC, Chikere BO. Bacterial diversity in a tropical crude oil-polluted soil undergoing bioremediation. Afr J Biotech. 2009; 8(11) 2535-2540.

Ciric L, Philip JC, Whiteley AS. Hydrocarbon utilization within a diesel-degrading bacterial consortium FEMS Microbiol Lett. 2010; 303; 116122.

Cowan ST. Cowan and steel's manual for the identification of medical bacteria Cambridge university Press Cambridge 1985.

Cunliffe M, Kertesz MA. Effect of Sphingobium yanoikuyae B1 inoculation on bacterial community dynamics and polycyclic aromatic hydrocarbon degradation in aged and freshly PAH-contaminated soils. Environ Poll. 2006; 144: 228-237.

Ghazali FM., Rahman RNA, Saleh AB, Basri, M. Biodegradation of hydrocarbons in soil by microbial consortium. Inter Biodeter and Biodegrad. 2004; 54: 61-67.

Hamamura N, Olson SH, Ward DM, Inskeep WP. Microbial population dynamics associated with crude oil biodegradation in diverse soils. Appl Environ Microbiol. 2006; 72: 6316-6324.

Hopper DR. Cleaning up contaminated wastesites. Chem Engine. 1989; 96: 94-110.

Huang XD, El-Alawi Y, Penrose DM, Glick B, Greenberg BM. A multiprocess phytoremediation system for removal of polycyclic aromatic hydrocarbons from contaminated soils. Environ Pollu. 2004:130; 465- 476.
Ijah UJJ, Antai SP. Removal of Nigerian light crude oil in soil over a $12-$ month period. Int Biodeterio Biodeg. 2003; 51: 93-99.

Ilori MO, Amund OO, Ezeani CJ, Omoijiahina S, Adebusoye SA. Occurrence and growth potentials of hydrocarbon degrading bacteria on the phylloplane of some tropical plants Afr J Biotechnol. 2006; 5(7): $542-454$

Jirasripongpun K. The characterization of oil-degrading microorganisms from lubricating oil contaminated (scale) soil. Lett Appl Microbiol. 2002; 35: 296-300.

Kaplan CW, Kitts CL. Bacterial succession in a petroleum land treatment unit. Appl Environ Microbiol. 2004; 70:1777-1786.

Kayode-Isola TM, Eniola KIT, Olayemi AB, Igunnugbemi OO. Response of Resident Bacteria of a Crude Oil-Polluted River to Diesel Oil. AmericanEurasian J Agro.2008; 1(1):06-09.

Kim JS,Crowley DE. Microbial diversity in natural asphalts of the Rancho La Brea Tar pits. Appl Environ Microbiol. 2007; 4579-4591

Kim S, Picardal FW. A novel bacterium that utilizes monochlorobiphenyls and 4-chlorobenzoate as growth substrates. FEMS Microbiol Lett. 2000; 185 : 225-229.

Leahy JG, Colwell RR. Microbial degradation of hydrocarbons in the environment, Microbiol Reviews. 1990; 54(3): 305-315.

MacNaughton SJ, Stephen JR, Venosa AD, Davis GA, Chang YJ, White DC. Microbial population changes during bioremediation of an experimental oil spill. Appl Environ Microbiol. 1999; 65:3566-3574.

Margesin R, Labbe D, Schinner F, Greer CW, Whyte LG. Characterization of hydrocarbon-degrading microbial populations in contaminated and pristine Alpine soils. Appl Environ Microbiol. 2003; 69:3085-3092.

Mihial DJ, Viraraghavan T, Jin YC. Bioremediation of petroleum-contaminated soil using composting. Practice Periodical Hazardous, Toxic Radioactive Waste Manage. 2006; 10: 108-115.

Nweke CO, Okpokwasili GC. Effects of bioremediation treatments on the bacterial populations of soil at different depths. Nig $J$ Microbiol. 2004; 18: 363-372.

Nwinyi OC, Nwodo CS, Amund OO. Biodegradation potential of two Rhodococcus strains capable of utilizing aniline as carbon source in tropical ecosystem. Res J Microbiol. 2008; 3(2): 99-104.

Nwinyi, OC. Enrichment and Identification of Askarel oil (PCB blend) degrading bacteria enriched from landfill sites in Edo State, Nigeria. Agr Biol J N Am. 2011; 2 (1): 89-100.

Okerentugba PO, Ezeronye, OU. Petroleum degrading potentials of single and mixed microbial cultures isolated from rivers and refinery effluent in Nigeria. Afr J Biotech. 2003; 2:288-292. 
Okpokwasili GC, James WA. Microbial contamination of kerosene, gasoline, and crude oil and their spoilage potentials. Mater Organismen. 1995; (29):147-156.

Olutiola PO, Famurela O, Sontag HE. An introduction to General Microbiology, a practical Approach Heideberger Verlagsanstalt and Druckerei $\mathrm{GmbH}$ Heldelberg Gmbh, Germany 1991.

Parales RE, Bruce CN, Schmid A, Wackett LP. Biodegradation, biotransformation, and biocatalysis (B3). Appl Environ Microbiol. 2002; 68(10):46994709.

Quatrini P, Scaglione G, De Pasquale C, Reila S, Puglia AM. Isolation of Gram-positive n-alkane degraders from a hydrocarbon contaminated Mediterranean shoreline. J Appl Microbiol. 2008; 104: 251- 259.
Riffaldi R, Saviozzi A, Cardelli R, Cipolli S, LeviMinzi R. Sulphur mineralization kinetics as influenced by soil properties. Biol Fert Soils. 2006; 43: 209-214.

Scullion J. Remediating polluted soils. Naturwissenschaften. 2006; 93: 51-65.

Van Beilen Beilen JB, Funhoff EG. Alkane hydroxylases involved in microbial alkane degradation. Appl Microbiol Biotechnol. 2007; 74: 13-21.

Wackett LP, Hershberger LCD. Biocatalysis and biodegradation: Microbial transformation of organic compounds. Washington: ASM Press. 2001. 